\title{
Life-cycle evaluation of nitrogen-use in rice-farming systems: implications for economically-optimal nitrogen rates
}

\author{
Y. Xia and X. Yan \\ State Key Laboratory of Soil and Sustainable Agriculture, Institute of Soil Science, Chinese Academy of Sciences, \\ Nanjing 210008, China
}

Received: 19 June 2011 - Published in Biogeosciences Discuss.: 5 July 2011

Revised: 23 October 2011 - Accepted: 24 October 2011 - Published: 7 November 2011

\begin{abstract}
Nitrogen $(\mathrm{N})$ fertilizer plays an important role in agricultural systems in terms of food yield. However, $\mathrm{N}$ application rates (NARs) are often overestimated over the rice (Oryza sativa L.) growing season in the Taihu Lake region of China. This is largely because negative externalities are not entirely included when evaluating economically-optimal nitrogen rate (EONR), such as only individual $\mathrm{N}$ losses are taken into account, or the inventory flows of reactive $\mathrm{N}$ have been limited solely to the farming process when evaluating environmental and economic effects of $\mathrm{N}$ fertilizer. This study integrates important material and energy flows resulting from $\mathrm{N}$ use into a rice agricultural inventory that constitutes the hub of the life-cycle assessment (LCA) method. An economic evaluation is used to determine an environmental and economic NAR for the Taihu Lake region. The analysis reveals that production and exploitation processes consume the largest proportion of resources, accounting for $77.2 \%$ and $22.3 \%$ of total resources, respectively. Regarding environmental impact, global warming creates the highest cost with contributions stemming mostly from fertilizer production and farming processes. Farming process incurs the biggest environmental impact of the three environmental impact categories considered, whereas transportation has a much smaller effect. When taking account of resource consumption and environmental cost, the marginal benefit of $1 \mathrm{~kg}$ rice would decrease from 2.4 to only 1.05 yuan. Accordingly, our current EONR has been evaluated at $187 \mathrm{~kg} \mathrm{Nha}^{-1}$ for a single rice-growing season. This could enhance profitability, as well as reduce the $\mathrm{N}$ losses associated with rice growing.
\end{abstract}

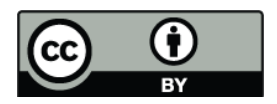

Correspondence to: X. Yan (yanxy@issas.ac.cn)

\section{Introduction}

Nitrogen $(\mathrm{N})$ fertilizer plays an important role in agricultural systems in terms of food yield, and both environmental and economic impact (UN-DSD, 2000). For China, there is a significant positive linear correlation between annual food production and annual chemical fertilizer-N (CF-N) consumption (Zhu and Chen, 2002). Nevertheless, excessive $\mathrm{N}$ fertilization has resulted in serious environmental problems and economic harm because of atmospheric, soil, and water enrichment by reactive $\mathrm{N}$ (Smith, 2003; Wang et al., 2004; Ju et al., 2009).

Economically-optimal $\mathrm{N}$ rate (EONR) strategies implemented in various agriculture systems have been welldocumented. The aim of the optimization is to maximize profit and reduce overall $\mathrm{N}$ application (Wang et al., 2004; Zhu, 2006; Liang et al., 2008). It is related to gross revenues associated with food production and mitigation of possible $\mathrm{N}$ permeation throughout ecosystems (Xia and Yan, 2011b). Therefore, a comprehensive analysis of $\mathrm{N}$ pathways associated with $\mathrm{N}$ use in agriculture systems is desirable to give more reliable valuations.

The environmental and economic impacts of $\mathrm{N}$ losses have been analyzed in numerous studies. However, these have largely focused only on specific effects such as ammonia volatilization, nitrogen oxide emission, or nitrate leaching (Bouwman, 1996; Brye et al., 2001; Emissions, 2008; Chen et al., 2010), but neglecting $\mathrm{N}$ permeation at regional scales. Moreover, inventory flows of reactive $\mathrm{N}$ were solely limited to $\mathrm{N}$ losses in the farming process, and neglected other processes, such as raw material exploitation, fertilizer production, and transportation, these processes consume utilities which in turn have environmental impacts. To examine and evaluate the entire environmental burden from the $\mathrm{N}$ fertilizer connection throughout agricultural production, it is necessary to consider concurrently the whole environmental impact of $\mathrm{N}$ losses (Brentrup et al., 2004; Kim and Dale, 2008).

Published by Copernicus Publications on behalf of the European Geosciences Union. 
Life Cycle Assessment (LCA) is a methodology designed to study just such impacts starting with the acquisition of raw materials, through to manufacture and use, and finally disposal (Payraudeau and van der Werf, 2005). In LCA, all aspects of such impact are related to one common valuation unit and are summarized according to environmental effects or aggregated into a comprehensive environmental index. This indexing allows the ranking of different products or production alternatives according to their overall environmental performance (Klöpffer, 1997). Developed primarily for industrial products, LCA has in more recent years been applied increasingly to agricultural production. With the incorporation of LCA into the ISO14040, more and more studies specifically applying LCA are needed to analyze environmental impacts resulting from human intrusion into ecosystems (ISO, 2006).

In China, the Taihu Lake region is known as a region where $\mathrm{N}$ application is intensive and $\mathrm{N}$ enrichment in soils, waterways and atmosphere has led to serious environmental problems (Zhu, 2006). To decrease $\mathrm{N}$ application rate (NAR) while maintaining relatively high economic returns as well as high rice yields, an EONR needs to be obtained. However, NARs is often overestimated as not all environmental impacts and processes associated with $\mathrm{N}$ use have been identified in evaluations from previous studies. For example, Zhu (2006) recommended an EONR, in which only the efficiency of the fertilizer $\mathrm{N}$ and its prime cost were considered. While the eutrophication cost is further added to the calculation, $\mathrm{Lu}$ and Cheng (2000) could not evaluate other aspects of environmental impact, such as global warming and acidification effects of $\mathrm{N}$ losses. In a more comprehensive study conducted by Xia and Yan (2011b), the focus was only on the farming process and did not specifically address problems and issues related to LCA within the $\mathrm{N}$ use chain. Therefore, there is a need to evaluate the overall environmental impact of $\mathrm{N}$ permeation from all $\mathrm{N}$ use, and provide a more reliable NAR during the rice-growing season in the Taihu Lake region.

In this paper, we introduced an LCA method that integrates the environmental effects stemming from the entire $\mathrm{N}$ cycle pertinent for a rice farming system in China. Three more important aspects of the environmental impact, viz. global warming, eutrophication, and acidification, were then synthesized under an economic valuation scheme. By this means, we derived a more reliable EONR that accounts for the environmental harm in $\mathrm{N}$-using processes caused in producing one kilogram of rice.

\section{Materials and methods}

\subsection{Study site}

The study was conducted in the Taihu Lake region in the eastern part of China $\left(30^{\circ} 5^{\prime}-32^{\circ} 8^{\prime} \mathrm{N}, 119^{\circ} 8^{\prime}-121^{\circ} 55^{\prime} \mathrm{E}\right)$. Historically, this is one of China's more ancient agricultural regions with a history of rice-wheat cultivation reaching back several thousands of years. Irrigated summer rice (Oryza sativa L.) has been grown in the region each year from June to October. Traditional manuring practices have almost been abandoned in favor of heavy mineral $\mathrm{N}$ fertilizer applications, at doses often above $300 \mathrm{~kg} \mathrm{~N} \mathrm{ha}^{-1}$ per crop. Current $\mathrm{N}$ fertilizer practices split the application into three periods each year, namely, a basal fertilizer (40-50\%) between 1630 June, topdressing at tillering (20\%) between 10-21 July, and topdressing at pinnacle initiation (30-40\%) between, $1-$ 21 August. The intermittent irrigation regime leads to high $\mathrm{N}$ conversion losses and low $\mathrm{N}$ uptake efficiencies by crops of $28-41 \%$ (Zhu and Wen, 1992). Detailed site information and $\mathrm{N}$ management over the rice-growing season have been previously described (Guo et al., 2004; Wang et al., 2004; Xia and Yan, 2011b).

\subsection{Life-cycle assessment}

The LCA methodology involves four major steps: goals and scope, life-cycle inventory, LCA, and interpretation (Nemecek, 2011; Heller, 2003). These are described separately below.

\subsubsection{Goals and scope}

The goals identify the purpose, scope and boundaries of the study, and the functional unit. In this study, the purpose of the analysis was to quantify and evaluate the impact of different processes of $\mathrm{N}$ permeation throughout the whole environment associated with rice production systems. To enable a ranking of the different processes encountered towards an overall environmental effectiveness, all impact values are given relative to a common unit, which is gain of $1 \mathrm{~kg}$ dry rice (at a water content of $12 \%$ ). The system boundary is subdivided into four main unit processes (Fig. 1), which are described as follows:

1. Energy exploitation: Energy is made ready for use as fuel or/and raw material in the phases of energy exploitation, urea production, transportation, and farming phase. Evaluation parameter of energy exploitation is the amount of energy consumption (unit: kJ) and pollution emission (unit: $\mathrm{g}$ ) to the environment for $1 \mathrm{~kg}$ energy production, the functional units of which are $\mathrm{kJ} \mathrm{kg}^{-1}$ and $\mathrm{g} \mathrm{kg}^{-1}$.

2. Fertilizer production: Domestic urea production is based mainly on coal, which account for about 80 percent of the total raw material and the rest is based on 


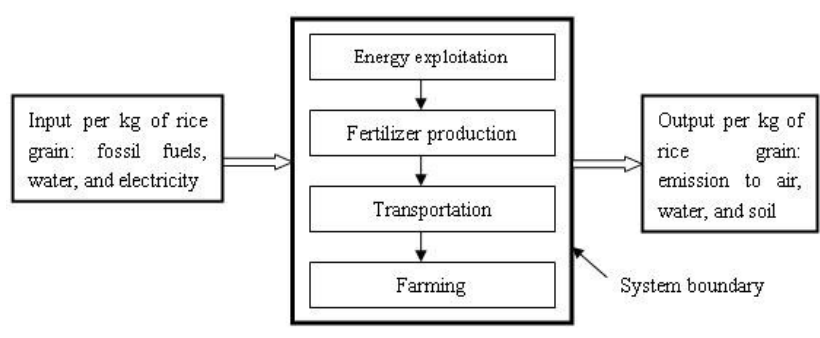

Fig. 1. System boundary and sub processes for the $\mathrm{N}$ use life-cycle of a rice farming system.

crude oil (Wang, 2010). Two processes are associated with fertilizer production, petrochemical manufacture of ammonia and its subsequent conversion into urea. The key chemical reactions in urea production are:

$\mathrm{N}_{2}+3 \mathrm{H}_{2} \leftrightarrow 2 \mathrm{NH}_{3}$

$2 \mathrm{NH}_{3}+\mathrm{CO}_{2} \leftrightarrow \mathrm{H}_{2} \mathrm{O}+\mathrm{NH}_{2} \mathrm{CONH}_{2}$ (urea)

3. Fertilizer transportation: the process of moving fertilizer from manufacturing outlets to farms by motor vehicles.

4. Farming: paddy-field farming practices that involve planting, growing, and harvest.

\subsubsection{Life-cycle inventory}

A life-cycle inventory involves essentially itemizing and quantifying all inputs and outputs of the analyzed system associated with the production of a single $1 \mathrm{~kg}$ of rice. We summarized the collected data and present such an inventory in Table 1.

According to the characteristics of energy production, it can be divided into two categories. First, all of the energy is used as a "fuel", such as coal which is completely combusted in power generation process. Second, energy is partly used as a process fuel, and the remaining part is taken as the raw materials, such as coal exploitation process. Some coal is used as fuel in combustion process (producing emissions), and the remaining part is utilized as a raw material (not producing emissions) such as fertilizer production process. The quantities of energy consumption in energy exploitation and fertilizer production processes can be obtained from literature and databases (Table 1).

Since most cities in the Taihu Lake region have their own manufacturing outlets of chemical fertilizer, the average transport distance was assumed to be $50 \mathrm{~km}$, the average distance of rural areas to the nearest city. The average energy consumption in transportation is 51 of gasoline for a vehicle with a $5 \mathrm{t}$ carrying capacity.

The environmental emission of energy consumption relate to calories is calculated by:

$\mathrm{TEM}_{j}=\sum\left(\mathrm{EF}_{\text {fuel }}, i^{j}+K_{1} \mathrm{EF}_{\text {pro }}, i^{j}+K_{2} \mathrm{EF}_{\text {raw }}, i^{j}\right)$
Where $K_{1}$ and $K_{2}$ are loss coefficient for exploitation and raw material phases, respectively; $\mathrm{TEM}_{j}$ is the total emission factor of No. j pollutant, $\mathrm{g} \mathrm{GJ}^{-1} ; \mathrm{EF}_{\mathrm{pro}, i}^{j}$ is the emission factor of the No. $j$ pollutant in the No. $i$ energy in the exploitation process, $\mathrm{g} \mathrm{GJ}^{-1}, \mathrm{EF}_{\text {raw }}, i^{j}$ is the emission factor of the No. $j$ pollutant in the No. $i$ energy used as raw material process, $\mathrm{g} \mathrm{GJ}^{-1}, \mathrm{EF}_{\text {fuel }}, i^{j}$ is No. $j$ pollutant direct emission factor of the No. $i$ fuel combustion, $\mathrm{g} \mathrm{GJ}^{-1}$. These emission factors are available from the literature (Zhang et al., 2009).

The total emission factors relate to $1 \mathrm{~kg}$ energy consumption $\left(\mathrm{TEF}_{j}\right)$ and $1 \mathrm{k} \mathrm{Wh}$ electricity could be calculated by the following equation

$\mathrm{TEF}_{j}=\mathrm{TEM}_{j} \times \mathrm{LHV}$

where LHV is low caloric value of the fuel, $\mathrm{GJ} \mathrm{kg}^{-1}$. International LHV is $2.27 \times 10^{-2}, 4.27 \times 10^{-2} \mathrm{GJ} \mathrm{kg}^{-1}$, and $3.69 \times 10^{-3} \mathrm{GJ} \mathrm{kW} \mathrm{h}^{-1}$ for coal, crude oil, and electricity, respectively (ESSOM, 2008). The calculation results are listed in Table 2.

In regard to the farming process, the rice production system analyzed in this study is an idealized typical system based on 10 long-established field experiments from 1995 to 2008 within the hotspots of the Taihu Lake region. Soils in this region typically are formed from alluvial loss deposits and can be classified as Typic Epiaquept (USDA, 2000). Climate and management details are almost similar in this region (Xia and Yan, 2011b). As compiled by Xia and Yan (2011b), the effects of different $\mathrm{N}$ rates on rice yields, $\mathrm{N}_{2} \mathrm{O}$ emission, $\mathrm{NH}_{3}$ volatilization, $\mathrm{NO}_{3}^{-}-\mathrm{N}$ and $\mathrm{NH}_{4}^{+}-\mathrm{N}$ lost through leaching and runoff were considered in the field experiments across the region. Based on the collected measurements, the statistical analyses showed that the $\mathrm{N}$ rate was a highly sensitive factor and could be used to model rice yields and $\mathrm{N}$ losses (Xia and Yan, 2011b). As a consequence, the fertilizer-induced yield gain $\left(F_{\text {yield }}\left(\mathrm{N}_{\text {rate }}\right), \mathrm{kg} \mathrm{ha}^{-1}\right)$ can be estimated by the following quadratic equation:

$$
\begin{aligned}
& F_{\text {yield }}\left(\mathrm{N}_{\text {rate }}\right)=(-0.032 \pm 0.005) \mathrm{N}_{\text {rate }}^{2} \\
& +(16.6 \pm 1.8) \mathrm{N}_{\text {rate }}\left(R^{2}=0.558, P<0.0001\right)
\end{aligned}
$$

The total $\mathrm{N}_{2} \mathrm{O}$ emission $\left[\mathrm{TE}_{\mathrm{N}_{2} \mathrm{O}}\left(\mathrm{N}_{\text {rate }}\right)\right], \mathrm{kg} \mathrm{Nha}^{-1}$ ) was estimated by an exponential equation:

$$
\begin{aligned}
& \mathrm{TE}_{\mathrm{N}_{2} \mathrm{O}}\left(\mathrm{N}_{\text {rate }}\right)=(0.31 \pm 0.05) \exp \\
& {\left[(0.0048 \pm 0.0005) \mathrm{N}_{\text {rate }}\right]\left(R^{2}=0.56, P<0.0001 .\right)}
\end{aligned}
$$

The average amount of $\mathrm{NH}_{3}$ volatilization $\left(F_{\mathrm{NH}_{3}}\left(\mathrm{~N}_{\text {rate }}\right)\right.$, $\mathrm{kg} \mathrm{Nha}^{-1}$ ) was about $18 \%$ of the total chemical $\mathrm{N}$ applied,

$$
\begin{aligned}
& F_{\mathrm{NH}_{3}}\left(\mathrm{~N}_{\text {rate }}\right)=(0.18 \pm 0.03) \times \mathrm{N}_{\text {rate }} \\
& \left(R^{2}=0.54, P<0.0001\right)
\end{aligned}
$$

There was a significant exponential relationship between the $\mathrm{N}$ rate and TN masses in leachate $\left(\mathrm{TL}_{\mathrm{TN}}\left(\mathrm{N}_{\mathrm{rate}}\right), \mathrm{kg} \mathrm{N} \mathrm{ha}^{-1}\right)$ 
Table 1. Inventory data of $\mathrm{N}$ use relate to $1 \mathrm{~kg}$ of rice when $300 \mathrm{~kg} \mathrm{~N}$ ha $^{-1}$ applied.

\begin{tabular}{|c|c|c|c|}
\hline Input/output & Source & Per $1 \mathrm{~kg}$ of rice & Reference \\
\hline \multirow[t]{4}{*}{ Fossil fuel } & Energy exploitation & $1.64 \mathrm{E}-01(\mathrm{~kg})$ & Ao $(2006)$ \\
\hline & Fertilizer production & $5.87 \mathrm{E}-01(\mathrm{~kg})$ & Xu et al. (2006) \\
\hline & Transportation & $9.38 \mathrm{E}-04(\mathrm{~kg})$ & Zhang and Huang (2007) \\
\hline & Farming & $1.07 \mathrm{E}-03(\mathrm{~kg})$ & Kasmaprapruet et al. (2009) \\
\hline \multirow[t]{2}{*}{ Electricity } & Energy exploitation & $2.50 \mathrm{E}-02(\mathrm{kWh})$ & Ao $(2006)$ \\
\hline & Fertilizer production & $7.40 \mathrm{E}-02(\mathrm{kWh})$ & Xu et al. (2006) \\
\hline \multirow[t]{2}{*}{ Water depletion } & Energy exploitation & $1.50 \mathrm{E}-03\left(\mathrm{~m}^{3}\right)$ & Ao $(2006)$ \\
\hline & Fertilizer production & $3.94 \mathrm{E}-03\left(\mathrm{~m}^{3}\right)$ & Xu et al. (2006) \\
\hline \multirow[t]{4}{*}{$\mathrm{CO}_{2}$} & Energy exploitation & $5.97 \mathrm{E}+01(\mathrm{~g})$ & Ao $(2006)$ \\
\hline & Fertilizer production & $1.97 \mathrm{E}+02(\mathrm{~g})$ & Zhang et al. (2009) \\
\hline & Fertilizer production & $1.87 \mathrm{E}-01(\mathrm{~g})$ & Di et al. (2005); Xu et al. (2006) \\
\hline & Transportation & $2.14 \mathrm{E}-01(\mathrm{~g})$ & Zhang and Huang (2007) \\
\hline \multirow[t]{4}{*}{$\mathrm{CH}_{4}$} & Energy exploitation & $4.38 \mathrm{E}-04(\mathrm{~g})$ & Ao $(2006)$ \\
\hline & Fertilizer production & $1.46 \mathrm{E}-03(\mathrm{~g})$ & Di et al. (2005); Xu et al. (2006) \\
\hline & Transportation & $2.02 \mathrm{E}-06(\mathrm{~g})$ & Zhang and Huang (2007) \\
\hline & Farming & $7.55 \mathrm{E}+00(\mathrm{~g})$ & Xiong et al. (1999) \\
\hline \multirow[t]{4}{*}{$\mathrm{N}_{2} \mathrm{O}$} & Energy exploitation & $5.79 \mathrm{E}-04(\mathrm{~g})$ & Zhang et al. (2009) \\
\hline & Fertilizer production & $1.91 \mathrm{E}-03(\mathrm{~g})$ & Zhang et al. (2009) \\
\hline & Transportation & $1.88 \mathrm{E}-06(\mathrm{~g})$ & Zhang and Huang (2007) \\
\hline & Farming & $6.34 \mathrm{E}-01(\mathrm{~g})$ & Xia and Yan (2011b); IPCC (2006) \\
\hline $\mathrm{NH}_{3}+\mathrm{NH}_{4}^{+}-\mathrm{N}$ & Farming & $2.41 \mathrm{E}+01(\mathrm{~g})$ & Xia and Yan (2011b) \\
\hline $\mathrm{NO}_{3}^{-}-\mathrm{N}$ & Farming & $8.40 \mathrm{E}+00(\mathrm{~g})$ & Xia and Yan (2011b) \\
\hline \multirow[t]{4}{*}{$\mathrm{SO}_{2}^{5}$} & Energy exploitation & $3.12 \mathrm{E}-01(\mathrm{~g})$ & Ao $(2006)$ \\
\hline & Fertilizer production & $1.02 \mathrm{E}-00(\mathrm{~g})$ & Di et al. (2005); Xu et al. (2006) \\
\hline & Transportation & $9.38 \mathrm{E}-04(\mathrm{~g})$ & Liu et al. (2009) \\
\hline & Farming & $1.07 \mathrm{E}-03(\mathrm{~g})$ & Kasmaprapruet et al. (2009) \\
\hline \multirow[t]{4}{*}{$\mathrm{NO}_{\mathrm{x}}$} & Energy exploitation & $2.04 \mathrm{E}-01(\mathrm{~g})$ & Ao $(2006)$ \\
\hline & Fertilizer production & $6.63 \mathrm{E}-01(\mathrm{~g})$ & Di et al. (2005); Xu et al. (2006) \\
\hline & Transportation & $5.63 \mathrm{E}-04(\mathrm{~g})$ & Liu et al. (2009) \\
\hline & Farming & $6.42 \mathrm{E}-04(\mathrm{~g})$ & Kasmaprapruet et al. (2009) \\
\hline
\end{tabular}

Table 2. Environmental emissions of energy consumption related to $1 \mathrm{~kg}$ energy consumption upstream phase.

\begin{tabular}{llllll}
\hline $\begin{array}{l}\text { Environmental } \\
\text { emissions factor* }\end{array}$ & $\mathrm{SO}_{2}$ & $\mathrm{CO}_{2}$ & $\mathrm{NO}_{\mathrm{x}}$ & $\mathrm{N}_{2} \mathrm{O}$ & $\mathrm{CH}_{4}$ \\
\hline Coal $\left(\mathrm{g} \mathrm{kg}^{-1}\right)$ & 0.4 & 89.2 & 0.4 & 0.001 & 0.001 \\
Crude oil $\left(\mathrm{g} \mathrm{kg}^{-1}\right)$ & 1.3 & 234.1 & 0.7 & 0.003 & 0.002 \\
Electricity & 5.9 & 1073.6 & 4.2 & 0.01 & 0.007 \\
$\left(\mathrm{~g} \mathrm{kWh}^{-1}\right)$ & & & & & \\
\hline
\end{tabular}

* Calculated by multiplying the environmental emission of energy consumption relate to calories $\left(\mathrm{g} \mathrm{GJ}^{-1}\right.$ ) (Zhang et al., 2009) by their respective low caloric value of the fuel $\left(\mathrm{GJ} \mathrm{kg}^{-1}\right)$.

and runoff ( $\left.\mathrm{TR}_{\mathrm{TN}}\left(\mathrm{N}_{\text {rate }}\right), \mathrm{kg} \mathrm{N} \mathrm{ha}^{-1}\right)$ during the rice-growing season:

$\mathrm{TL}_{\mathrm{TN}}\left(\mathrm{N}_{\text {rate }}\right)=(1.10 \pm 0.21) \exp \left[(0.0038 \pm 0.0006) \mathrm{N}_{\text {rate }}\right](6)$ $\left(R^{2}=0.50, P<0.001\right)$,
$\mathrm{TR}_{\mathrm{TN}}\left(\mathrm{N}_{\text {rate }}\right)=(8.29 \pm 2.11) \exp \left[(0.0042 \pm 0.0009) \mathrm{N}_{\text {rate }}\right](7)$ $\left(R^{2}=0.51, P<0.001\right)$.

Based on the above calculated quantities of $\mathrm{NH}_{3}$ volatilization and $\mathrm{N}$ leaching and runoff, we estimated indirect $\mathrm{N}_{2} \mathrm{O}$ emission $\left(\mathrm{ID}_{N_{2}} \mathrm{O}, \mathrm{kg} \mathrm{Nha}^{-1}\right.$ ) induced by fertilizer application using IPCC methodology (IPCC, 2006).

$\mathrm{ID}_{\mathrm{N}_{2} \mathrm{O}}=F_{\mathrm{NH}_{3}} \times \mathrm{EF}_{4}+\left(\mathrm{TL}_{\mathrm{TN}}+\mathrm{TR}_{\mathrm{TN}}\right) \times \mathrm{EF}_{5}$

$\mathrm{EF}_{4}$ is IPCC emission factor for $\mathrm{N}_{2} \mathrm{O}$ emissions from atmospheric deposition of $\mathrm{N}$ on soils and water surfaces (default as $\left.0.01 \mathrm{~kg} \mathrm{~N}_{2} \mathrm{O}-\mathrm{N}\left(\mathrm{kg} \mathrm{NH}_{3}-\mathrm{N} \text { volatilized }\right)^{-1}\right)$, and $\mathrm{EF}_{5}$ is IPCC emission factor for $\mathrm{N}_{2} \mathrm{O}$ emissions from $\mathrm{N}$ leaching and runoff (default as $0.0075 \mathrm{~kg} \mathrm{~N}_{2} \mathrm{O}-\mathrm{N}$ ( $\mathrm{kg} \mathrm{N}$ leached and

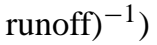

In this paper, the above concrete relationship between the $\mathrm{N}$ rates, rice production and $\mathrm{N}$ losses are used in assessing final depositions of $\mathrm{N}$ fertilizer for a rice production system in the Taihu Lake region. As the mean NAR is about $300 \mathrm{~kg} \mathrm{~N} \mathrm{ha}^{-1}$ for a single rice season (Ju et al., 2009), we 
can derive the inventory data associated with the marginal rice production and the total marginal quantities for all $\mathrm{N}$ losses in the farming process. The inventory data of $1 \mathrm{~kg}$ rice at $300 \mathrm{~kg} \mathrm{~N} \mathrm{ha}^{-1}$ was then calculated as the marginal quantities of each type divided by the marginal rice production.

\subsubsection{Life-cycle impact assessment}

The life-cycle impact assessment involves procedures whereby environmental impact of each of the inventory entries can be assessed, and the overall environmental performance of the product is determined (Charles et al., 2006). Impact assessment incorporates three stages: classification, characterization and valuation. In the first stage, outputs are classified according to the type of environmental problem, i.e. whether this is global warming, eutrophication, or acidification effects. Characterization quantifies the relative contribution of each input or output in regard to each environmental problem according to an impact score (Brentrup et al., 2001) (Table 3). The higher the equivalence factor, the greater is the contribution of an emission to the respective effect.

To assist in a comparison of various facets of an environmental impact that have been quantified initially in heterogeneous units, the valuation is performed by weighing these facets so that an overall value can be obtained for the total extent of the environmental effects. This is the most contentious stage of the LCA, and the most subjective (Craighill and Powell, 1995), because it involves trade-offs between different environmental problems. A relatively new alternative, which is described in detail in Moomaw and Birch (2005) and Xia and Yan (2011b), is to use economic valuation methodologies to value environmental and social costs and their benefits. In summary, the cost of each type of material was determined according to their respective average market price. According to the cost evaluation of acid rain in China, the damage cost of $1 \mathrm{~kg} \mathrm{SO}_{2}$ equivalent in acidification is 5.0 yuan. The costs of $1 \mathrm{~kg} \mathrm{PO}_{4}$ equivalent in eutrophication is evaluated as 4.26 yuan by sum of external costs of fishery, tourism and habitation, together with the treatment cost of water companies for $\mathrm{NO}_{3}-\mathrm{N}$ and $\mathrm{NH}_{4}^{+}-\mathrm{N}$ removal in the Taihu Lake Region. The cost of $1 \mathrm{~kg} \mathrm{CO}_{2}$-equivalent global warming potential is 0.15 yuan, which was deduced by international market price of $\mathrm{CO}_{2}$ for 2008 (Xia and Yan, 2011b). The external cost of managing one ton of each material and the environmental effect are displayed in Table 3.

\subsubsection{Interpretation}

In the last step of a LCA, results that have been extracted are used to identify hot-spots and the possibilities of reducing the negative environmental effects of the systems under analysis.
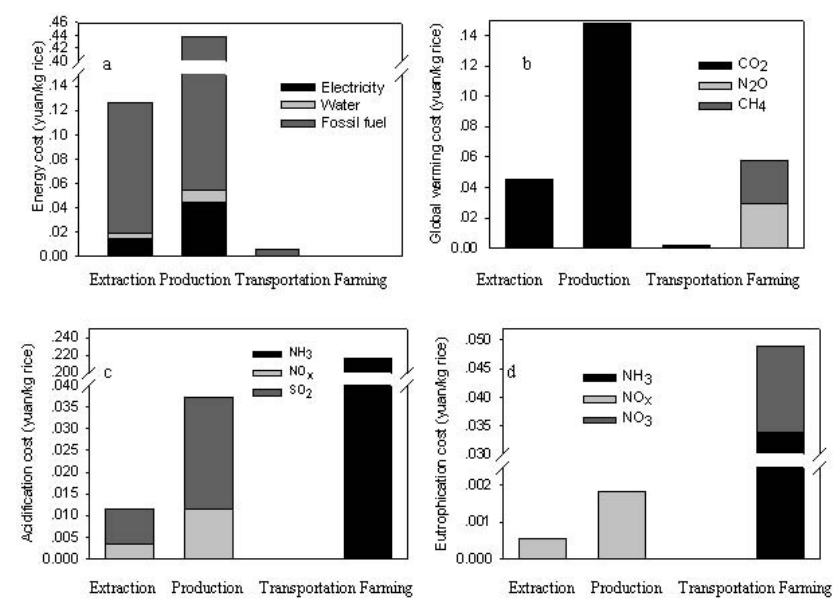

Fig. 2. (a) energy consumption cost, (b) global warming cost, (c) acidification cost, and (d) eutrophication cost of $\mathrm{N}$ use life cycle related to $1 \mathrm{~kg}$ rice production when $300 \mathrm{~kg} \mathrm{~N} \mathrm{ha}^{-1}$ applied.

\section{Results}

\subsection{Resource usage}

There are great differences in economic importance between processes and resources usage. As shown in Fig. 2a, the production process is the largest resource consumer, contributing $77.2 \%$ of the resource cost in total, and is followed by the exploitation process $(22.3 \%)$. For these two processes, fossil fuel consumption contributes $84.9 \%$ and $87.4 \%$ of their respective resource usage in total. When comparing their economic costs to gain $1 \mathrm{~kg}$ of rice, the fossil fuel cost is as high as 0.11 and 0.38 yuan $\mathrm{kg}^{-1}$ rice for the exploitation process and the $\mathrm{N}$ production process, respectively. Electricity is the second costly consumed resource, equivalent to 0.04 yuan $\mathrm{kg}^{-1}$ rice for production process and 0.02 yuan $\mathrm{kg}^{-1}$ rice for exploitation process. Water depletion is also an important contributor to resource consumption in material exploitation and $\mathrm{N}$ fertilizer production processes, amount to 0.01 yuan $\mathrm{kg}^{-1}$ rice for the total process considered; whereas, it is ignored in the farming process as water irrigation is not directly associated with the amount of $\mathrm{N}$ used.

\subsection{Environmental impacts}

Three impact categories, viz. global warming, acidification, and eutrophication, were considered in terms of equivalent quantities of the relevant reference substance. Economic valuations recast in homogenous units were further used to aggregate inventory results. 
Table 3. Aggregation (classification and characterization) of $\mathrm{N}$ use life cycle.

\begin{tabular}{|c|c|c|c|c|}
\hline Impact category & Contributing elements & Characterization factors* & Cost $* *$ & unit \\
\hline \multirow{3}{*}{ Resource consumption } & Raw minerals use & 1 & 1.90 & $\mathrm{~kg}$ \\
\hline & Electricity & 1 & 0.60 & $\mathrm{kWh}$ \\
\hline & Water consumption & 1 & 2.70 & $\mathrm{~m}^{3}$ \\
\hline \multirow{4}{*}{ Global warming } & $\mathrm{CO}_{2}$ & 1 & \multirow{4}{*}{0.15} & \multirow{4}{*}{$\mathrm{kg} \mathrm{CO}_{2}$ equiv. } \\
\hline & $\mathrm{CH}_{4}$ & 25 & & \\
\hline & $\mathrm{N}_{2} \mathrm{O}$ & 310 & & \\
\hline & $\mathrm{NH}_{3}, \mathrm{NH}_{4}^{+}$ & 1.88 & & \\
\hline \multirow[t]{3}{*}{ Acidification } & NOx & 0.7 & \multirow[t]{3}{*}{5.00} & \multirow[t]{3}{*}{$\mathrm{kg} \mathrm{SO}_{2}$ equiv. } \\
\hline & $\mathrm{SO}_{2}$ & 1 & & \\
\hline & $\mathrm{NOx}$ & 0.13 & & \\
\hline \multirow[t]{2}{*}{ Eutrophication } & $\mathrm{NO}_{3}^{-}$ & 0.42 & \multirow[t]{2}{*}{4.26} & \multirow[t]{2}{*}{$\mathrm{kg} \mathrm{PO}_{4}$ - equiv. } \\
\hline & $\mathrm{NH}_{4}^{+}, \mathrm{NH}_{3}$ & 0.33 & & \\
\hline
\end{tabular}

* Referenced from Brentrup et al. (2001); ** Referenced from Xia and Yan (2011b)

\subsubsection{Global warming}

Figure $2 b$ presents a bar graph of the results after weighting. The figure indicates that the highest global warming contribution accrues from the fertilizer production process, which accounts for $58.5 \%$ of total global warming costs, followed successively by farming $(23.0 \%)$, exploitation $(17.9 \%)$, and transportation $(0.6 \%)$ processes. In regard to impacts of different global warming gases, $\mathrm{CO}_{2}$ emissions are important in all phases. The emission of $\mathrm{CO}_{2}$ provides $95.2 \%$ of the total global warming potential in the production process, and the total resulting cost is as high as 0.15 yuan $\mathrm{kg}^{-1}$ rice. For the farming process, $\mathrm{N}_{2} \mathrm{O}$ and $\mathrm{CH}_{4}$ emissions are almost important global warming gas sources, both cost about 0.02 yuan $^{-1}$ rice, respectively.

\subsubsection{Acidification}

The emissions of $\mathrm{NH}_{3}, \mathrm{NO}_{\mathrm{x}}$, and $\mathrm{SO}_{2}$ contribute to acidification differently in $\mathrm{N}$-use processes (Fig. 2c). Though $\mathrm{NH}_{3}$ released into the atmosphere neutralizes acid oxidation products of sulphur and nitrogen oxides in precipitation, this will results in a substantial increase in $\mathrm{pH}$ of precipitation. Once deposited in soil or water, the ammonium compounds may be oxidized to nitric acid (Schuurkes and Mosello, 1988; Brentrup et al., 2001). The majority of acid gas is emitted as $\mathrm{NH}_{3}$ in the farming process, with smaller amounts of $\mathrm{NO}_{\mathrm{x}}$, and $\mathrm{SO}_{2}$ emission in other processes. Accordingly, its acidification cost is estimated to be as high as 0.22 yuan $\mathrm{kg}^{-1}$ rice, contributing $81.7 \%$ to the total acidification cost. The production process is the dominant source of $\mathrm{NO}_{\mathrm{x}}$ and $\mathrm{SO}_{2}$ emission, contributing $14.0 \%$ to the total acidification cost, whereas acidification is potentially very low in the exploitation and transportation processes (together adding $4.3 \%$ of total acidification cost).

\subsubsection{Eutrophication}

Eutrophication represents the contribution of $\mathrm{N}$ or phosphorus $(\mathrm{P})$ to river and lakes that can create oxygen-starved conditions in the bottom strata owing to increased algal growth. For the rice production system in the Taihu Lake Region, the farming process contributes greatest to eutrophication $(95.2 \%)$, followed by production $(3.6 \%)$, exploitation $(1.1 \%)$, and transportation $(0.1 \%)$ processes (Fig. 2d). Among the environmental impacts, $\mathrm{NH}_{3}$ volatilization and nitrate leaching that occurred in the farming process, are the largest eutrophication sources, costing 0.034 and 0.015 yuan $\mathrm{kg}^{-1}$ rice, respectively. While other processes emitted the largest amount $\mathrm{NO}_{\mathrm{x}}$ emissions, emissions of $\mathrm{NO}_{\mathrm{x}}$ contribute least to eutrophication, with a cost of 0.002 yuan $\mathrm{kg}^{-1}$ rice.

\section{Discussion}

\subsection{Life-cycle impact assessment}

We introduced LCA method to evaluate the environmental impact of $\mathrm{N}$-use in a given rice production system. Previous common environmental evaluations focused only on individual effects or $\mathrm{N}$ permeation in the farming process (Wang et al., 2004; Kim and Dale, 2008; Xia and Yan, 2011b). Very few studies have concurrently considered all environmental impacts associated with the entire $\mathrm{N}$-use processes. This is likely due to the lack of an effective evaluation method to account for the cascade of $\mathrm{N}$ fluxes. Outside the industrial applications, for which it was original designed, LCA is an evolving quantitative tool that has the potential to be used in various areas. The central concept of LCA is to combine, with a small number of indicators, pollutant emissions and resources utilized over a product life-cycle (Burgess and Brennan, 2001). For this reason, the method is applicable to rice farming systems. It enables a comprehensive analysis of all other environmental impacts related to such systems. This 


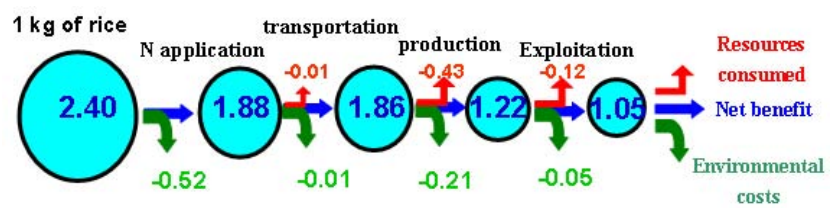

Fig. 3. Total economic cost of resource usage and environmental impacts for $\mathrm{N}$ use life cycle related to $1 \mathrm{~kg}$ rice production (yuan $\mathrm{kg}^{-1}$ rice) when $300 \mathrm{~kg} \mathrm{~N} \mathrm{ha}^{-1}$ applied.

is currently of particular interest because of increasing public concern and interest in the environmental impact of food production (Zhu and Chen, 2002).

The consideration of sub-processes in LCA quantifies the environmental impacts of each process, which then allows the identification of contentious environmental hot-spots in the total production system. As illustrated by life-cycle inventories of rice production, resource usage of production and exploitation processes was a great contribution to the cost of $\mathrm{N}$ application (Fig. 3). As such, reducing $\mathrm{N}$ fertilizer and increasing their production efficiencies are key points to decrease resource consumption. With respect to the environmental impact, the most significant pollution impact happened in the farming process, amount to 0.51 yuan $\mathrm{kg}^{-1}$ rice for the total environmental costs considered, followed by fertilizer production $\left(0.18\right.$ yuan $\mathrm{kg}^{-1}$ rice) and raw material exploitation (0.06 yuan $\mathrm{kg}^{-1}$ rice) processes (Fig. 3), whereas transportation has a much smaller effect. This suggests that we should pay more attention to farming activities to minimize those environmental burdens throughout the $\mathrm{N}$ cycle. As the mean NAR is about $300 \mathrm{~kg} \mathrm{~N} \mathrm{ha}^{-1}$ for a single rice season in the Taihu Lake region, the marginal benefit of $1 \mathrm{~kg}$ rice would decrease from 2.4 to only 1.05 yuan when resources and environmental costs are subtracted (Fig. 3).

This study has ranked different aspects of environmental impact through a single unit-based economic evaluation. It is helpful for regulators and researchers to adopt the most effective means of abatement, and accordingly may encourage a closer look at the environmental impact of industrial agriculture as a whole. Our results showed that global warming contributes the greatest cost, with 0.25 yuan $\mathrm{kg}^{-1}$ rice in total. Other studies have also shown that it plays an important role in corn and soybean cultivation in terms of both economic and environmental aspects (Landis et al., 2007; Kim and Dale, 2008). Nevertheless, the impact of global warming has been ignored in most previous studies that evaluated the environmental degradation resulting from $\mathrm{N}$ application (Yadav et al., 1997; Lu and Cheng, 2000; Zhu, 2006). This underestimated the environmental impact of $\mathrm{N}$ use, and accordingly may lead to the neglect of related measurements. As acidification and eutrophication result mostly from the farming process, reducing $\mathrm{NH}_{3}$ emission and $\mathrm{NO}_{3}^{-}$runoff/leaching in farming activities are especially important if decreases in environmental impact from $\mathrm{N}$ use in rice production systems are desired.

\subsection{Implications to economically optimal nitrogen rates}

Economic effects of $\mathrm{N}$ fertilizer rates on crop production have been documented by many studies (Lambert et al., 2006; Zhu, 2006; Hernandez and Mulla, 2008). Due to the response of rice yields and environmental impacts to NARs, researchers have been trying to determine regional EONR to maximize profit (Roelcke et al., 2004; Zhu, 2006). In contrast to these studies, most began only with a particular goal or target to improve N-use efficiency, ignoring NAR effects on the environmental impact of rice production Wang et al. (2004) suggested that sustainable cropping systems (in terms of total environment cost equal to the prime cost of fertilizer) can be achieved by applying an appropriate NAR, but detailed guidance was not given. This may bring maximum returns for farm owners, but not necessarily lead to maximum net returns that benefit the public, although it requires the integration of environmental impacts.

Only a few studies have actually considered the environmental impact of $\mathrm{N}$ use. Estimations of EONR over a ricegrowing season differed one from another due to different environmental issues being considered. However, these overestimated EONRs as not all aspects of the environmental impact and processes associated with $\mathrm{N}$ use had been included in the evaluation. In the Taihu Lake region, Zhu (2006) only considered the efficiency of the fertilizer $\mathrm{N}$ and its prime cost, and obtained a result of $218 \mathrm{~kg} \mathrm{Nha}^{-1}$ over a ricegrowing season. Including eutrophication costs, the resulting EONR was $327.8-371.6 \mathrm{~kg} \mathrm{~N} \mathrm{ha}^{-1}$ for the entire rice and wheat-growing season, as obtained by $\mathrm{Lu}$ and Cheng (2000). In a more comprehensive study conducted by Xia and Yan (2011b), the EONR was $202 \mathrm{~kg} \mathrm{Nha}^{-1}$ for a rice-growing season if acidification, global warming, and eutrophication costs were calculated altogether. In this study, not only were the whole environmental costs considered, but also process costs associated with the entire $\mathrm{N}$ chain were evaluated. If we assume there is a linear relationship between NAR and its environmental impact, with the exception of the farming process, our current EONR that yields a maximum public benefit is estimated to be as low as $187 \mathrm{~kg} \mathrm{Nha}^{-1}$ (Fig. 4), implying that any further increase in NAR generates no additional profit but an environmental burden.

Our method may provide a means to quantify EONR and maximize economic return over a rice season in the Taihu Lake region. As admitted by Xing and Zhu (2000), there is great potential in reducing the current amounts of $\mathrm{N}$ applied in rice production systems of the Taihu Lake region, but detailed reasons were not given. From the economic perspective presented in this study, the $\mathrm{N}$-stimulated rice production benefit would decrease from 5150 to 4849 yuan ha $^{-1}$ (a $5.84 \%$ decrease) if synthetic $\mathrm{N}$ fertilizer application rates decreased from $300 \mathrm{~kg} \mathrm{~N} \mathrm{ha}^{-1}$ to $187 \mathrm{~kg} \mathrm{~N} \mathrm{ha}^{-1}(38.67 \%$ decrease). This would lead to an approximate $38.6 \%$ decrease in resource usage and environmental cost during a single rice-growing season. As a result, the net economic benefit 


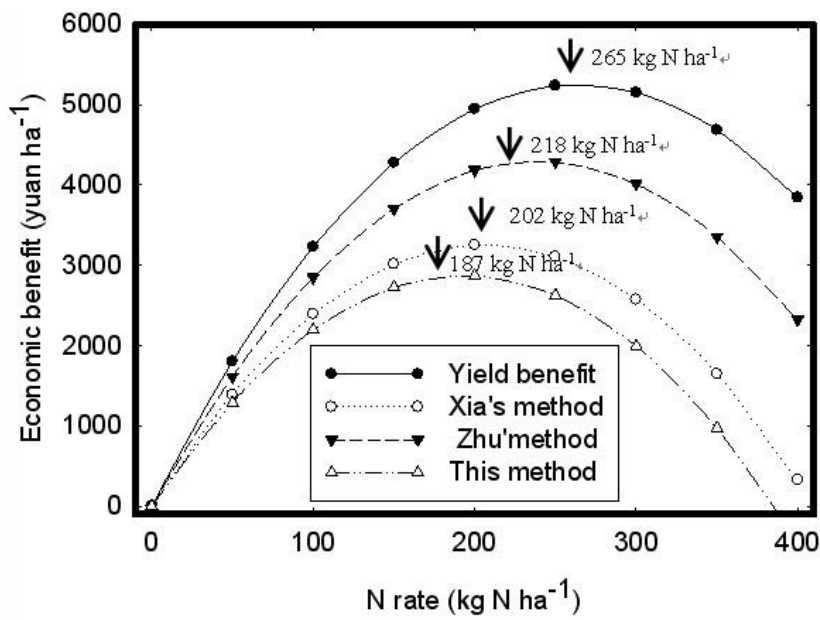

Fig. 4. Comparison with EONR and economic benefit for different evaluation methods, in which Zhu (2006) considered the efficiency of the fertilizer $\mathrm{N}$ and its prime cost, Xia and Yan (2011b) included acidification, global warming, and eutrophication costs during ricegrowing season.

was 2798 yuan ha ${ }^{-1}$ at a $\mathrm{N}$ rate of $187 \mathrm{~kg} \mathrm{Nha}^{-1}, 920$ yuan greater than that at a $\mathrm{N}$ rate of $300 \mathrm{~kg} \mathrm{~N} \mathrm{ha}^{-1}$. This difference would greatly increase the net benefit to society and diminish the $\mathrm{N}$ burden on soil, water and air resources in the Taihu Lake region, which has approximately 330000 ha of paddy soil.

\subsection{Improvement potentials}

For the rice-wheat cropping cycle in the Taihu Lake region, there are currently no long term experiments conducted to determine the interaction of decreasing the fertilizer $\mathrm{N}$ input in rice season on the following wheat crop and changing wheat production management on the next rice crop. However, many relatively short term experiments indicated that reduction in fertilizer $\mathrm{N}$ use in rice does not have any impacts on the following wheat crop. A four-year summer rice and three-year winter wheat study (1995-1998), conducted at two sites in the Taihu Lake region, showed that reducing synthetic N use by roughly 30\%-45\% from "standard" application rate (farmer's field practice, about $300 \mathrm{~kg} \mathrm{Nha}^{-1}$ for rice season and $250 \mathrm{~kg} \mathrm{~N} \mathrm{ha}^{-1}$ for wheat season) did not statistically decrease wheat yield, regardless of whether the reduction of $\mathrm{N}$ application rate occurred in the rice or wheat season (Roelcke et al., 2004). However, Nitrogen balance surpluses under "reduced" fertilization diminished by about $80 \%$ for summer rice and $60 \%$ for winter wheat compared to the "standard" treatment. In a lysimeter experiment with undisturbed soil profiles carried out in a paddy soil under a rice-wheat system in the same region, reducing synthetic $\mathrm{N}$ use from $300 \mathrm{~kg} \mathrm{Nha}^{-1}$ to $150 \mathrm{~kg} \mathrm{Nha}^{-1}$ in rice crop did not decrease the following wheat yield significantly, but reduced
$\mathrm{N}$ losses of $\mathrm{NH}_{3}$ by $68 \%$, runoff by $64 \%$, and leaching by $85 \%$ (Wang et al., 2007). By summarizing datasets from field experiments and demonstration trials of rice-wheat between 1995 and 2008 (Xia and Yan, 2011c, b), we concluded that decreasing the fertilizer $\mathrm{N}$ input from $300 \mathrm{~kg} \mathrm{Nha}^{-1}$ to our recommendation of $185 \mathrm{~kg} \mathrm{~N} \mathrm{ha}^{-1}$ in rice season did not have any impacts on the following wheat crop. The decreased application $\mathrm{N}$ rate would otherwise greatly reduce $\mathrm{N}$ losses and increase economic benefits for the whole ricewheat cropping systems.

There also was much evidence that a good management of nutrients in wheat season can improve wheat yield while having less impact on the next rice crop. In the site-specific $\mathrm{N}$ management (SSNM) system, the $\mathrm{N}$ fertilizer rates were applied by three split doses (the ratio of basal fertilizer: first topdressing: second topdressing was 3:1:1) (Liang et al., 2008). According to wheat season statistical data from the Taihu Lake region, the economic $\mathrm{N}$ application rate is around $193 \sim 218 \mathrm{~kg} \mathrm{Nha}^{-1}$, which is $10 \%$ to $40 \%$ lower than the prevailing $\mathrm{N}$ application rate, and nevertheless, would have less impacts on the next rice yield (Xia and Yan, 2011a,c). Another possible management was based on knowledgebased optimum $\mathrm{N}$ recommendation (KONR), which could cut one-third of the current $\mathrm{N}$ application rate without loss of yield (Zhu, 2006; Ju et al., 2009). In a typical study conducted by Wang et al. (2007) in the Taihu Lake region, reducing $\mathrm{N}$ application rate from 250 to $125 \mathrm{~kg} \mathrm{~N} \mathrm{ha}^{-1}$ did not affect rice yield significantly, regardless along with decreasing $\mathrm{N}$ application rate from 300 to $150 \mathrm{~kg} \mathrm{Nha}^{-1}$ in rice season Roelcke et al. (2004) also addressed a reduction or increase fertilizer application in wheat crop would not have any significant effects on the next rice crop. Although some others management of nutrients in wheat season, such as interplanting with zero tillage and wheat straw manuring (Wang, 2002; Liu et al., 2007), may affect the optimal $\mathrm{N}$ application rate and rice yield, these managements are relatively not common in the Taihu Lake region.

Therefore, there are great potentials to reduce fertilizer $\mathrm{N}$ use without loss of yield for the following wheat or the next rice crop. However, there are conceptual, institutional, and socio-economy factors for farmers to over-apply fertilizer N. There has been, however, considerable progress obtained in farmer acceptance of optimal $\mathrm{N}$ recommendations in the Taihu Lake region. The most important reason may arise from the differences in the perception of how a crop on an individual field actually responds to fertilizer (Rajsic and Weersink, 2008; Xia and Yan, 2011a). Most farmers generally took the relationship between fertilizer application and crop yield for a linear function. Another reason would be the difference in economics benefit calculation. The profit-maximizing $\mathrm{N}$ rates for farmers are determined by the crop yield and the prime cost of fertilizer $\mathrm{N}$ and they do not need to consider and pay for environmental problems of $\mathrm{N}$ losses. Recently, with more and more younger farmers leaving the country side for construction or factory jobs in 
the city after sowing their fields, they do not have much time to manage their field and apply a larger amount of $\mathrm{N}$ to compensate (Chen et al., 2011).

In achieving an optimal $\mathrm{N}$ future, increasing public and institutional awareness of both benefits and threats of $\mathrm{N}$ are urgently needed. These could be achieved by government policies and public participation in the context of the agricultural $\mathrm{N}$ management challenge. Governments can employ several kinds of strategies, including improved communication and education, the incentivization of good $\mathrm{N}$ management practice. The International Nitrogen Initiative (INI, 2010) is a good example of an organization that has made increasing use of the internet for communication. It aims to increase awareness of the $\mathrm{N}$ challenge and to enhance the integration of stakeholder expertise and activity. It is hoped that maximal benefits of human society's interaction with the global $\mathrm{N}$ cycle could be achieved if ecologically optimum $\mathrm{N}$ rates are adopted.

\section{Conclusions}

The LCA method was used to evaluate the environmental impact of $\mathrm{N}$ application for a typical rice farming system from raw material exploitation to arable farming processes. We used economic values to weigh the potential of each impact category, and a monetary database to derive weights of the environmental impact categories for a single kilogram of rice produced. This evaluation revealed environmental hot-spots in the total production system and allowed for a clear ranking of different environmental impact factors under a common economic evaluation scheme. As a result of this strategy, a sharp decrease in EONR is expected over a single ricegrowing season in China's Taihu Lake region, attributable to a more comprehensive inclusion of environmental impact factors. Although long term experiments are needed to determine the interactions of $\mathrm{N}$ management between the rice and wheat production seasons, our EONR should enhance farm profitability and reduce environmental impacts.

Acknowledgements. This study was supported by the Natural Science Foundation of Jiangsu Province (BK2010609), the National Key Basic Research Project of China (2009CB118600), and the Chinese Academy Sciences Innovation Program (KZCX2-YW440).

Edited by: A. R. Mosier

\section{References}

Ao, H. G.: Life cycle assessment of the heating oil and coal in Wangjiaweizi Dist. Daqing. Haerbin, 1-82, 2006.

Bouwman, A. F.: Direct emission of nitrous oxide from agricultural soils, Nutr. Cycl. Agroecosys., 46, 53-70, 1996.
Brentrup, F., Küters, J., Kuhlmann, H., and Lammel, J.: Application of the Life Cycle Assessment methodology to agricultural production: an example of sugar beet production with different forms of nitrogen fertilizers, Eur. J. Agron., 14, 221-233, 2001.

Brentrup, F., Küsters, J., Kuhlmann, H., and Lammel, J.: Environmental impact assessment of agricultural production systems using the life cycle assessment methodology I., Theoretical concept of a LCA method tailored to crop production, Eur. J. Agron., 20, 247-264, 2004.

Brye, K. R., Norman, J. M., Bundy, L. G., and Gower, S. T.: Nitrogen and Carbon Leaching in Agroecosystems and Their Role in Denitrification Potential, J. Environ. Qual. 30, 58-70, 2001.

Burgess, A. A. and Brennan, D. J.: Application of life cycle assessment to chemical processes, Chem. Eng. Sci., 56, 2589-2604, 2001.

Charles, R., Jolliet, O., Gaillard, G., and Pellet, D.: Environmental analysis of intensity level in wheat crop production using life cycle assessment, Agr. Ecosyst. Environ., 113, 216-225, 2006.

Chen, C. R., Phillips, I. R., Wei, L. L., and Xu, Z. H.: Behaviour and dynamics of di-ammonium phosphate in bauxite processing residue sand in Western Australia-I. NH3 volatilisation and residual nitrogen availability, Environ. Sci. Pollut. Res., 17, 1098-1109, 2010.

Chen, J., Huang, Y., and Tang, Y.: Quantifying economically and ecologically optimum nitrogen rates for rice production in southeastern China, Agr. Ecosyst. Environ., 142, 195-204, 2011.

Craighill, A. L. and Powell, J. C.: Lifecycle assessment and economic evaluation of recycling: A case study, Resour. Conserv. Recy., 17, 75-96, 1995.

Di, X. H., Nie, Z. R., and Zuo, T. Y.: Life cycle emission inventories for the fuels consumed by thermal power in China, Chin. Environ. Sci. , 25, 632-635, 2005 (in Chinese).

Emissions, A.: Ammonia Assessment from Agriculture: US Status and Needs, J. Environ. Qual., 37, 515-520, 2008.

ESSOM: Heating values of hydrogen and fuels, available at:http: //www.essom.com/backend/data-file/engineer/engin21\{_\}1.pdf, 2008.

Guo, H. Y., Zhu, J. G., Wang, X. R., Wu, Z. H., and Zhang, Z.: Case Study on Nitrogen and Phosphorus Emissions from Paddy Field in Taihu Region, Environ. Geochem. Health., 26, 209-219, 2004.

Heller, M. C. and Keoleian, G. A.: Assessing the sustainability of the US food system: a life cycle perspective, Agric. Syst., 76, 1007-1041, 2003.

Hernandez, J. A. and Mulla, D. J.: Estimating uncertainty of economically optimum fertilizer rates, Agron. J., 100, 1221-1229, 2008.

INI: International Nitrogen Initiative, available at:www.initrogen. org, 2010.

IPCC: 2006 IPCC Guidelines for National Greenhouse Gas Inventories, Hayama, Japan, 1-12, 2006.

ISO: International Organization for Standardization. Environmental management - life cycle assessment - principles and framework, ISO 14040, available at:http://www.iso.org/iso, 2006.

Ju, X. T., Xing, G. X., Chen, X. P., Zhang, S. L., Zhang, L. J., Liu, X. J., Cui, Z. L., Yin, B., Christie, P., and Zhu, Z. L.: Reducing environmental risk by improving $\mathrm{N}$ management in intensive Chinese agricultural systems, Proc. Nat. Acad. Sci., 106, 30413046, 2009. 
Kasmaprapruet, S., Paengjuntuek, W., Saikhwan, P., and Phungrassami, H.: Life cycle assessment of milled rice production: case study in Thailand, Eur. J. Sci. Res., 30, 195-203, 2009.

Kim, S. and Dale, B. E.: Effects of nitrogen fertilizer application on greenhouse gas emissions and economics of corn production, Environ. Sci. Technol, 42, 6028-6033, 2008.

Klöpffer, W.: Life cycle assessment: From the beginning to the current state, Environ. Sci. Pollut. Res., 4, 223-228, 1997.

Lambert, D. M., Lowenberg-Deboer, J., and Malzer, G. L.: Economic analysis of spatial-temporal patterns in corn and soybean response to nitrogen and phosphorus, Agron. J., 98, 43-54, 2006.

Landis, A. E., Miller, S. A., and Theis, T. L.: Life Cycle of the CornSoybean Agroecosystem for Biobased Production, Environ. Sci. Technol., 41, 1457-1464, 2007.

Liang, X. Q., Li, H., He, M. M., Chen, Y. X., Tian, G. M., and $\mathrm{Xu}, \mathrm{S}$. Y.: The ecologically optimum application of nitrogen in wheat season of rice wheat cropping system, Agron. J., 100, 6772, 2008.

Liu, J. Y., Li, J., He, C., Li, X. X., and Qian, Y.: Life cycle cost analysis of coal-fired power generation and its alternatives, J. Chin. Coal Soc., 34, 1435-1440, 2009.

Liu, S., Nie, X., Dai, Q., Huo, Z., and Xu, K.: Effects of Interpolating with Zero Tillage and Wheat Straw Manuring on Rice Growth and Grain Quality, Chin. J. Rice Sci., 21, 71-76, 2007 (in Chinese with English abstract).

Lu, Y. and Cheng, X.: Nitrogen pollution from agricultural nonpoint source in Lake Tai Region and its environmental eonomic analysis, Shanghai Environ. Sci., 19, 143-148, 2000 (in Chinese).

Lu, Y. and Cheng, X.: Nitrogen pollution from agricultural nonpoint source in Lake Tai Region and its environmental economic analysis, Shanghai Environ. Sci., 19, 143-148, 2000 (in Chinese).

Moomaw, W.R. and Birch, M.B.: Cascading costs: an economic nitrogen cycle. Sci. Chin. Ser. C-Life Sci. 48:678-696, 2005.

Nemecek, T., Huguenin-Elie, O., Dubois, D., Gaillard, G., Schaller, B. and Chervet, A.: Life cycle assessment of Swiss farming systems: II. Extensive and intensive production, Agric. Syst., 103, 233-245, 2011.

Payraudeau, S. and van der Werf, H. M. G.: Environmental impact assessment for a farming region: a review of methods, Agr. Ecosyst. Environ., 107, 1-19, 2005.

Rajsic, P. and Weersink, A.: Do farmers waste fertilizer? A comparison of ex post optimal nitrogen rates and ex ante recommendations by model, site and year, Agric. Syst., 97, 56-67, 2008.

Roelcke, M., Han, Y., Schleef, K. H., Zhu, J. G., Liu, G., Cai, Z. C., and Richter, J.: Recent trends and recommendations for nitrogen fertilization in intensive agriculture in eastern China, Pedosphere, 14, 449-460, 2004.

Schuurkes, J. A. A. R. and Mosello, R.: The role of external ammonium inputs in freshwater acidification, Aquatic SciencesResearch Across Boundaries, 50, 71-86, 1988.

Smith, V. H.: Eutrophication of freshwater and coastal marine ecosystems a global problem, Environ. Sci. Pollut. Res., 10, 126139, 2003.

UN-DSD: Promoting sustainable agriculture and rural development, United Nations (UN), New York, 2000.

USDA: Water quality impacts of agriculture. United States, Washington, 2000.
Wang, D. J., Liu, Q., Lin, J. H., and Sun, R. J.: Optimum nitrogen use and reduced nitrogen loss for production of rice and wheat in the Yangtse Delta region, Environ. Geochem. Health., 26, 221227, 2004.

Wang, L.: Urea Industry in China, available at:http://www.sinofi. com/english/show_news.asp?id=525, 2010.

Wang, X. Z., Zhu, J. G., Guo, R., Yasukazu, H., and Feng, K.: Nitrogen Cycling and Losses Under Rice-Wheat Rotations with Coated Urea and Urea in the Taihu Lake Region, Pedosphere, 17, 62-69, 2007.

Wang, Z.: Effect of the Straw Returned into Soil in Rice and Wheat Planting Area in Taihu Region, J. Anhui Agric. Sci., 30, 269271, 2002 (in Chinese).

Xia, Y. and Yan, X.: Comparison of statistical models for predicting cost effective nitrogen rate at rice-wheat cropping systems. Soil Sci. Plant Nutr., 57:320-330, 2011a.

Xia, Y. and Yan, X.: Ecologically optimal nitrogen application rates for rice cropping in the Taihu Lake region of China, Sustain. Sci., in press, doi:10.1007/s11625-011-0144-2. 2011b.

Xia, Y. and Yan, X.: Recommendations for nitrogen fertilizer with integrated agronomic, environmental, and economic benefits for wheat season in Taihu Lake region, Acta Pedol. Sin., 48, 12091217, 2011c (in Chinese).

Xing, G. X. and Zhu, Z. L.: An assessment of N loss from agricultural fields to the environment in China, Nutr. Cycl. Agroecosys., 57, 67-73, 2000.

Xiong, X. Z., Shen, R. X., and Wang, M. X.: Methane emissions from rice paddy fields of Taihu area, Chin. J. Atmos. Sci., 23, 9-18, 1999 (in Chinese).

Xu, T. B., Ma, Y. T., Ren, G., and Wang, Y. Q.: Environmental assessment of project for ammonia combination and urea production in Ltd. AnQi, Hebei Science and Technology Publishing House, Shijiazhuang, China, 2006 (in Chinese).

Yadav, S. N., Peterson, W., and Easter, K. W.: Do farmers overuse nitrogen fertilizer to the detriment of the environment? Environ. Resour. Econ., 9, 323-340, 1997.

Zhang, L. and Huang, Z. Life cycle assessment of methanolgasoline and its greenhouse gas emission for transportation, Design \& Manufacture of Diesel Engine, 15, 26-30, 2007 (in Chinese).

Zhang, X., Wang, J. and Huang, Z.: Life cycle assessment on energy consumption of building materials production, available at:http://www.inive.org/members_area/medias/pdf/Inive $\backslash$ protect $\backslash$ relax $\backslash$ kern.16667em $\{\%\} 5$ CIAQVEC2007\protect $\backslash$ relax $\backslash$ kern.16667em $\{\%\}$ 5CZhang_5.pdf, 2009.

Zhu, Z. L.: On the methodology of recommendation for the application rate of chemical fertilizer nitrogen to crops, Plant Nutr. Fert. Sci., 12, 1-4, 2006 (in Chinese).

Zhu, Z. L. and Wen, Q. X.: Nitrogen in soils of China, Jiangsu Science and Technology Publishing House, Nanjing, China, 1992 (in Chinese).

Zhu, Z. L. and Chen, D. L.: Nitrogen fertilizer use in China - Contributions to food production, impacts on the environment and best management strategies, Nutr. Cyc. Agroecosys., 63, 117127, 2002. 